\title{
The Effect of Intellectual Capital and Individual Self-Efficacy on Sport Identity of Kradeniz Technique University Physical Education Students
}

\author{
Elif Aydin \\ Correspondence: Elif Aydin, Faculty of Physical Education and Sport Sciences, Gumuhshaneh University, Turkey.
}

Received: March 19, 2019

doi:10.11114/jets.v7i10S.4453
Accepted: August 7, $2019 \quad$ Online Published: August 13, 2019

URL: https://doi.org/10.11114/jets.v7i10S.4453

\begin{abstract}
The purpose of this study was to investigate the effect of intellectual capital and individual self-efficacy on the sporting identity of the students in the field of physical education in Turkey. In order to measure the intellectual capital variable, the standard questionnaire (Bontis, 1998) was used, to measure the individual self-efficacy variable the standard questionnaire (Sherr \& Mados, 1982) was used, and to assess the sport identity of the standard questionnaire (Cheslak, 2004) was used.

The reliability of the questionnaires was also assessed by Cronbach's alpha test, respectively; The Cronbach's alpha coefficient for the intellectual capital questionnaire was 0.84 , for the self-efficacy questionnaire 0.75 and for the sports identity questionnaire 0.8 . The questionnaires were distributed among the statistical sample (181 students of physical education of Karadeniz Technique University). The findings indicated that intellectual capital with a coefficient of 0.85 and its three dimensions (human capital, structural capital, and communicative capital) as well as individual selfefficacy with a coefficient of 0.815 and its three dimensions (no interest in harassing others, desire of extending effort and different ways to face obstacles) on physical education students' identity was significant. It can be concluded that with the increase of intellectual capital and the efficiency of physical education students, the identity of sports identity will be improved.
\end{abstract}

Keywords: intellectual capital, individual self-efficacy, sports identity

\section{Introduction}

The importance psychologists have recently made in the role of psychological problems in improving athletic abilities was unprecedented (Daniels et al., 2005). Nowadays, with the increase of investment in professional sport, improvement in athletic performance has been increasingly taken into consideration and sports psychologists believe that the psychological variables of athletes play a key role in individual and team performance. They argue that coaches should not only focus on exercising their skills, but also on mental skills of individuals and teams (Anderson, 2009).

Athletes are more familiar with physical fields than other areas, and they are overlooked in terms of skill and mind. This is because the implementation of a better technique that leads to more success depends on the athlete's positive psychological components. Positive psychological components are also helpful in performance and increasing positive psychological energy (Prowais, 2012). Researchers who are interested in the effects of psychological factors on exercise and who are interested in the progression of participants in exercise and practice programs often focus on the selfconcept or attitude of athletes (Mills \& Christensen, 2006).

Cabrita and Rosado (2014) believe that identity is one of the important psychological factors in athletes. Identity is defined as the identity of the person and the others. From his point of view, identity is a psychosocial construct that involves mindset, individual beliefs, and how it communicates with others. According to Ericsson, our identity is constantly changing with any new information we get in our daily interactions with others. Identity has different types, from which it can be from individual to personal identity, family identity, national identity, religious identity, social identity, cultural identity, and sport identity (Cabrita \& Rosa da, 2014).

The sporting identity is defined by the degree of strength and degree that a person identifies as an athlete and is committed to his sports partnership (Boyle \& Magnusson, 2007). A strong sporting identity can lead to the motivation needed for a regular and regular athlete in the exercise as well as success at high levels of athletics (Yu and Anderson, 
2008). This could indicate that strong sporting identity has positive effects on the performance and athletic performance, fitness, fitness, and self-esteem of the athlete (Borensa et al., 2012).

Various variables can affect people's athletic identity and bring it up or down in athletes. It seems that people who have a good intellectual capital can better get their own intellectual capital to gain athletic identity Suitable for moving (Yang and Chai, 2018). Also, individuals with an appropriate self-efficacy, which is a cognitive assessment of individuals in terms of their ability to perform a task, can be better able to become effective in identifying sports in accordance with their personal abilities (Salih \& Qawkhan, 2015).

Intellectual capital is a set of knowledge, information, intellectual property, experience, competition, and learning among individuals that can be used to create ability (Lumina \& Allen, 2016: 196). In fact, the intellectual capital of all individuals encompasses its knowledge and abilities to create value in activities and activities (Robert and Darius, 2016). Intellectual capital has three dimensions: human capital, structural capital and communication capital (Francesca \& Lucia, 2017).

Human capital is defined as individual knowledge, skills, abilities and experiences in individuals to create value and solve problems (William et al., 2018).

Structural capital refers to existing structures and processes: 70 within an activity that individuals use and thus use their knowledge and skills (Philip \& Zelia, 2018).

Also, Communication capital is the connection between individuals in a particular group or category (Jason et al., 2017). Individual self-efficacy is also the cognitive assessment of individuals in terms of their ability to perform tasks of an activity (Jolien et al., 2018).

Individual self-efficacy is a factor that can affect the increase or improvement of some skills in individuals (Nicola et al., 2018). Bandura believes that self-efficacy is a constructive power by which the ability of individuals to perform assignments for an activity or occupation and to achieve different goals is effectively organized (Chong et al., 2014).

In his opinion, human belief in his abilities in doing things is effective in his actions (Sörj et al., 2018). Because the cognitive view states that humans shape their behavior based on the effects of possible reinforcements, and, for particular behaviors, make self-efficacy judgments about how well they pay attention to their behavior in order to achieve their desired results. Therefore, human behavior can be predicted based on possible outcomes and personal selfefficacy. In terms of athletic identity, individual self-efficacy can provide the motivation and insight needed in individuals to develop an appropriate sports identity (Han \& New, 2010).

According to mentioned results, in this research, we try to investigate the effect of intellectual capital and individual self-efficacy on the sporting identity of physical education students of Karadeniz Technique University. It seems that intellectual capital and its three dimensions: human capital, structural capital and relationship capital have a significant effect on the sporting identity of the students, as well as individual self-efficacy and its triple dimensions; the lack of interest in harassing others, the desire to expand an attempt and a different method in dealing with barriers to the sporting identity of the students have a significant effect on education.

\section{Methods}

The present research is applied, descriptive and correlational in terms of the type of method. Therefore, in terms of data collection method is a survey strategy. The statistical population of this study is all physical education students of Karadeniz Technique University, whose number is 342, and a sample size of 181 was determined using the Morgan table. The statistical sample was selected by simple random sampling method. In order to measure the intellectual capital variable, the standard questionnaire (Bontis, 1998) was used and to measure the individual self-efficacy variable the standard questionnaire (Sherr \& Mados, 1982) was used and to assess the sport identity, the standard questionnaire (Cheslak, 2004) was used.

Cronbach's alpha test was used to measure reliability. The Cronbach's alpha coefficient for the intellectual capital questionnaire was 0.84 , for the self-efficacy questionnaire (0.75) and for the sports identity questionnaire (0.8). For statistical analysis of the research data, simple and multivariate regression analysis has been used. 


\section{Results}

3.1 The Study of the Effect of Intellectual Capital on Sport Identity of Physical Education Students of Karadeniz Technique University by Simple Regression Test

Table 1. Results of simple regression coefficient

\begin{tabular}{|c|c|c|c|c|c|c|}
\hline \multirow[t]{2}{*}{ Model } & & \multicolumn{2}{|c|}{ Unstand. Coefficients } & \multirow{2}{*}{$\begin{array}{c}\text { Stand. Coefficients } \\
\text { Beta }\end{array}$} & \multirow[t]{2}{*}{$\mathrm{t}$} & \multirow[t]{2}{*}{ Sig. } \\
\hline & & B & Std. Error & & & \\
\hline & (Constant) & .415 & .102 & & 4.081 & .000 \\
\hline 1 & $\begin{array}{l}\text { Intellectual } \\
\text { Capital }\end{array}$ & .859 & .033 & .850 & 26.003 & .000 \\
\hline
\end{tabular}

a. Dependent Variable: Sports identity

According to the results of table and considering that the significance level of the test, error is less than 0.01, it can be said that intellectual capital has a significant positive effect on the sporting identity of Karadeniz Technique University physical education students. Also, the beta coefficient shows that intellectual capital predicts 0.85 out of the variations in the Karadeniz Technique University physical education. It can be concluded that by increasing the intellectual capital of physical education students, sports identity will also be improved.

3.2 Investigating the Impact of the Three Dimensions of Intellectual Capital; "Human Capital, Structural Capital, and Relative Capital" on the Athletic Identity of Physical Education Students in Karadeniz Technique University Physical Education by Using Multivariate Regression

Table 2. Results of Multivariate Regression

\begin{tabular}{|c|c|c|c|c|c|c|}
\hline \multicolumn{2}{|c|}{ Model } & \multicolumn{2}{|c|}{ Unstand. Coefficients } & \multirow{2}{*}{$\frac{\text { Stand. Coefficients }}{\text { Beta }}$} & \multirow[t]{2}{*}{$\mathrm{t}$} & \multirow[t]{2}{*}{ Sig. } \\
\hline & & B & Std. Error & & & \\
\hline \multirow{4}{*}{1} & (Constant) & .407 & .102 & & 3.988 & .000 \\
\hline & Human Capital & .319 & .033 & .378 & 9.602 & .000 \\
\hline & Structural capital & .307 & .036 & .360 & 8.506 & .000 \\
\hline & Communication capital & .237 & .036 & .288 & 6.629 & .000 \\
\hline
\end{tabular}

According to the results of table, and with regard to the beta coefficients, it can be said that the highest predictive power with the coefficient of 0.378 is related to the dimension of "human capital" and after the dimension of "structural capital" with a coefficient of beta of 0.36 and "communication capital" with The beta coefficient of 0.288 is at the next level, which predicts the sporting identity of physical education students at Karadeniz Technique University. It can be concluded that the dimension of human capital, more than two other dimensions, improves the athletic identity of the students, after which structural capital and communication capital are used, which also improve the student's athletic identity with less power.

3.3 A Survey on the Effect of Individual Self-efficacy on the Physical Education of Physical Education Students in Universal Unified Team Technique Using Simple Regression Test

Table 3 Simple regression coefficient results

\begin{tabular}{|c|c|c|c|c|c|c|}
\hline \multirow[t]{2}{*}{ Model } & & \multicolumn{2}{|c|}{ Unstandardized Coefficients } & \multirow{2}{*}{$\begin{array}{c}\text { Standardized } \\
\text { Coefficients }\end{array}$} & \multirow[t]{2}{*}{$\mathrm{t}$} & \multirow[t]{2}{*}{ Sig. } \\
\hline & & B & Std. Error & & & \\
\hline \multirow[b]{2}{*}{1} & (Constant) & .781 & .101 & & 7.757 & .000 \\
\hline & $\begin{array}{l}\text { Individual } \\
\text { self-efficacy }\end{array}$ & .704 & .031 & .815 & 22.696 & .000 \\
\hline
\end{tabular}

a. Dependent Variable: Sports identity

According to the results of the table, and considering that the significance level of the test error is less than 0.01, it can be concluded that individual self-efficacy has a significant positive effect on the physical education students at Karadeniz Technique University. 
Also, the beta coefficient shows that individual self-efficacy predicts 0.815 of the variations in the physical education students at Karadeniz Technique University. It can be concluded that by increasing self-efficacy of physical education students, sports identity will also be improved.

3.4 Investigating the Effect of Three Dimensions of Individual Self-efficacy; "Being Uninterested in Harassing Others; the Desire to Expand Efforts; A Different Approach to Facing Barriers"; on the Sporting Identity of Karadeniz Technique Physical Education Students of Using the Multivariate Regression Test

Table 4. Results of Multivariate Regression

\begin{tabular}{|c|c|c|c|c|c|c|}
\hline \multirow{2}{*}{\multicolumn{2}{|c|}{ Model }} & \multicolumn{2}{|c|}{$\begin{array}{l}\text { Unstandardized } \\
\text { Coefficients }\end{array}$} & \multirow{2}{*}{$\begin{array}{c}\text { Standardized } \\
\text { Coefficients }\end{array}$} & \multirow[t]{2}{*}{$\mathrm{t}$} & \multirow[t]{2}{*}{ Sig. } \\
\hline & & B & Std. Error & & & \\
\hline \multirow{4}{*}{1} & (Constant) & .791 & .100 & & 7.922 & .000 \\
\hline & Uninterested in harassing others & .290 & .031 & .386 & 9.414 & .000 \\
\hline & The desire to expand the effort & .310 & .031 & .402 & 10.128 & .000 \\
\hline & Different way to deal with obstacles & .413 & .031 & .556 & 13.542 & .000 \\
\hline
\end{tabular}

a. Dependent Variable: Sport identity

According to the results of table, and with regard to the beta coefficients, it can be said that the maximum predictive power with the coefficient of 0.556 is related to the dimension "different method in dealing with obstacles" and after the dimension of "desire to expand effort" with a beta coefficient of 0.402 and "not interested in being harassed by others" with a beta score of 0.386 are next up, predicting the dependent variable (sport identity Karadeniz Technique students). It can be concluded that the next "different way to deal with obstacles", more than two other dimensions, improves the athletic identity of the students, and then "desire to expand the effort" and "lack of interest in harassing others", which they also Athletic identity improves the ability of students with less power.

\section{Results}

In this research, the effect of intellectual capital and individual self-efficacy on the sporting identity of physical education students of Karadeniz Technique University has been investigated. The results showed that intellectual capital had a significant positive effect on the sporting identity of Karadeniz Technique University physical education students. Also, the beta coefficient shows that intellectual capital predicts 0.85 out of the variations in the Karadeniz Technique University physical education students.

It can be concluded that by increasing the intellectual capital of physical education students, sport identity will be improved. Also, the highest predictive power with a coefficient of 0.378 is related to the dimension of "human capital" and subsequently, the dimensions of "structural capital" with beta coefficients of 0.36 and "communication capital" with a beta coefficient of 0.288 are at a later stage, which predict the sporting identity of Karadeniz Technique University physical education students.

It can be concluded that the dimension of human capital improves the athletic identity of the students more than two other dimensions, after which structural capital and communication capital are used, which also improve the student's athletic identity with less power. The results of this section were aligned with Michel and Jeffrey (2018) and Proview (2012).

The results also showed that individual self-efficacy has a significant positive effect on the physical fitness of undergraduate students. Also, the beta coefficient shows that individual self-efficacy predicts 0.815 of the variations in Karadeniz Technique University physical education students. It can be concluded that by increasing self-efficacy of physical education students, sports identity will also be improved.

Also, the highest predictive power with a coefficient of 0.556 is related to the dimension "different Method in facing obstacles" and after the dimension of "desire to expand effort" with a beta coefficient of 0.402 and "no interest in harassing others" with a beta coefficient of 0.386 The next step is to predict the dependent variable (physical identity of Karadeniz Technique University physical education students).

It can be concluded that the next "Different way to deal with obstacles", more than two other dimensions, improves the athletic identity of the students, and then "desire to expand the effort" and "lack of interest in harassing others", which they also Athletic identity improves the ability of students with less power. The results of this section were consistent with Bornsa et al. (2017), Boyle and Magnusson (2007). 


\section{References}

Andersoon, B. (2009). Contribution of athletic identity to child and adolescent physical activity. American journal of preventive medicine, 37(3), 220-226. https://doi.org/10.1016/j.amepre.2009.05.017

Beatson, N. J., Berg, D. A., \& Smith, J. K. (2018). The impact of mastery feedback on undergraduate students' self-efficacy beliefs. Studies in Educational Evaluation, 59, 58-66. https://doi.org/10.1016/j.stueduc.2018.03.002

Bontis, N. (1998). Intellectual capital: an exploratory study that develops measures and models. Management Decision, 36(2), 63-76. https://doi.org/10.1108/00251749810204142

Boyle, B. A., \& Magnusson, P. (2007). Social identity and brand equity formation: A comparative study of collegiate sports fan. Journal of Sport Management, 21(4), October, 497-520. https://doi.org/10.1123/jsm.21.4.497

Burns, G. N., Jasinski, D., Dunn, S. C., \& Fletcher, D. (2012). Athlete identity and athlete satisfaction: The nonconformity of exclusivity. Personality and Individual Differences, 52(3), 280-284. https://doi.org/10.1016/j.paid.2011.10.020

Cabrita, T. M., Rosado, A. B., Leite, T. O., Serpa, S. O., \& Sousa, P. M. (2014). The relationship between athletic identity and career decisions in athletes. Journal of Applied Sport Psychology, 26(4), 471-481. https://doi.org/10.1080/10413200.2014.931312

Cieslak, T. J. (2004). Describing and measuring the athletic identity construct scale development and validation. Doctoral dissertation, The Ohio State University, Columbus.

da Motta Veiga, S. P., \& Turban, D. B. (2018). Insight into job search self-regulation: Effects of employment self-efficacy and perceived progress on job search intensity. Journal of Vocational Behavior, 108, 57-66. https://doi.org/10.1016/j.jvb.2018.06.010

Daniels, E., Sincharoen, S., \& Leaper, C. (2005). The relation between sport orientations and athletic identity among adolescent girl and boy athletes. Journal of Sport Behavior, 28(4), 315-332.

Geerlings, J., Thijs, J., \& Verkuyten, M. (2018). Teaching in ethnically diverse classrooms: Examining individual differences in teacher self-efficacy. Journal of school psychology, 67, 134-147. https://doi.org/10.1016/j.jsp.2017.12.001

Gilbert, J. H., Von Ah, D., \& Broome, M. E. (2017). Organizational intellectual capital and the role of the nurse manager: A proposed conceptual model. Nursing outlook, 65(6), 697-710. https://doi.org/10.1016/j.outlook.2017.04.005

Gogan, L. M., Artene, A., Sarca, I., \& Draghici, A. (2016). The Impact of Intellectual Capital on Organizational Performance. Procedia-Social and Behavioral Sciences, 221(7), 194-202. https://doi.org/10.1016/j.sbspro.2016.05.106

Han-Jen, N. (2010). Investigating the effects of self-efficacy on foodservice industry employees' career commitment, International Journal of Hospitality Management, 29(4), 743-750. https://doi.org/10.1016/j.ijhm.2010.03.006

Li, Y. Q., \& Liu, C. H. S. (2018). The role of problem identification and intellectual capital in the management of hotels' competitive advantage-an integrated framework. International Journal of Hospitality Management, 75, 160-170. https://doi.org/10.1016/j.ijhm.2018.05.022

McDowell, W. C., Peake, W. O., Coder, L., \& Harris, M. L. (2018). Building small firm performance through intellectual capital development: Exploring innovation as the "black box". Journal of business research, 88, 321-327. https://doi.org/10.1016/j.jbusres.2018.01.025

Michelle, G., \& Jeffrey, M. (2018). Para Sport Athletic Identity from Competition to Retirement: A Brief Review and Future Research Directions. Physical Medicine and Rehabilitation Clinics of North America, 29(2), 387-396. https://doi.org/10.1016/j.pmr.2018.01.007

Mills, A. L., \& Christensen, S. A. (2006). Athletic identity and its relationship to sport participation levels. Journal of Science and Medicine in Sport, 9(6), 472-478. https://doi.org/10.1016/j.jsams.2006.04.004

Proios, M. (2012). Athletic identity \& achievement goals of gymnastics athletes. Science of Gymnastics Journal, 4(1), $15-24$.

Robert, Ł., \& Dariusz, W. (2016). Intellectual Capital within the Project Management. Procedia Engineering, 153, 384-391. https://doi.org/10.1016/j.proeng.2016.08.137 
Salih, A., \& Gokhan, A. (2015). The Effect of Production Management Course on the Self-Efficacy of Employees. Procedia - Social and Behavioral Sciences, 197(25), 108-112. https://doi.org/10.1016/j.sbspro.2015.07.064

Sardo, F., Serrasqueiro, Z., \& Alves, H. (2018). On the relationship between intellectual capital and financial performance: A panel data analysis on SME hotels. International Journal of Hospitality Management, 75, 67-74. https://doi.org/10.1016/j.ijhm.2018.03.001

Sheerer, M., \& Maddus, J. (1982). The self-efficacy scale construction and validation psychology. Journal of Psychology Report, 51, 663-671. https://doi.org/10.2466/pr0.1982.51.2.663

Tejedo-Romero, F., Rodrigues, L. L., \& Craig, R. (2017). Women directors and disclosure of intellectual capital information. European Research on Management and Business Economics, 23(3), 123-131. https://doi.org/10.1016/j.iedeen.2017.06.003

Wang, C. J., Tsai, H. T., \& Tsai, M. T. (2014). Linking transformational leadership and employee creativity in the hospitality industry: The influences of creative role identity, creative self-efficacy, and job complexity. Tourism Management, 40, 79-89. https://doi.org/10.1016/j.tourman.2013.05.008

Yue, H. L., \& Andersen, J. (2008). Validation of the athletic identity measurement scale with a Hong Kong sample. IJSEP, 6. 176-188. https://doi.org/10.1080/1612197X.2008.9671860

\section{Copyrights}

Copyright for this article is retained by the author(s), with first publication rights granted to the journal.

This is an open-access article distributed under the terms and conditions of the Creative Commons Attribution license which permits unrestricted use, distribution, and reproduction in any medium, provided the original work is properly cited. 